AGRICULTURE AND BIOLOGY JOURNAL OF NORTH AMERICA

ISSN Print: 2151-7517, ISSN Online: 2151-7525, doi:10.5251/abjna.2013.4.4.422.429

C 2013, ScienceHuß, http://www.scihub.org/ABJNA

\title{
Estimating the determinants of poverty among artisanal fishing households in Edu and Moro local government areas of Kwara State, Nigeria
}

\author{
Y. U. Oladimeji, Z. Abdulsalam; M. A. Damisa and D. F. Omokore. \\ Department of Agricultural Economics and Rural Sociology, Ahmadu Bello University, P.M.B. \\ 1044, Zaria, Kaduna State, Nigeria \\ Corresponding author's e-mail:yusuf.dimeji@yahoo.com
}

\begin{abstract}
The study examined poverty and estimate its determinants among artisanal fishery households in Edu and Moro Local Government Areas of Kwara State. A multi stage random sampling technique was used to select 160 fishermen for the study. Primary data were obtained with the aid of well structured questionnaire and interview schedule. Descriptive statistics and tobit regression model were employed in the analysis of the data. $69.4 \%$ of pooled fishermen did not have formal schooling and about $91 \%$ were males. Using the maximum likelihood estimation technique. Asymptotic parameter estimates were evaluated to describe poverty determinants. Except for age, marital status and fishing experience, all other explanatory variables specified in the tobit model were significant. It is recommended that artisanal fishermen in the study area should be educated to ensure proper understanding of new fishing methods and adopt technology capable of increasing not only the profitability of the enterprise and improvement in the quality of life of rural households but also make efficient use of the fishing resources.
\end{abstract}

Key words: Artisanal, Poverty, Fishing households, Tobit model.

\section{INTRODUCTION}

Nigeria is one of the most resource endowed nations in the world. For instance, in terms of agricultural resources, Nigeria has a land area of 98.3 million hectares, out of which 79 million hectares is arable land. Between $60-70 \%$ of the population is involved in agriculture and agricultural related industries contributing a large share of GDP (Udolisa et al., 1994; FAO, 2013). The country is also endowed with coastline of about 800 kilometres, a continental shelf of about $256,000 \mathrm{~km}^{2}$ and exclusive economic zone area of $210,900 \mathrm{~km}^{2}$. The topography of the coastal area is straddled by the drainage systems of Rivers Niger and Benue as well as their main tributaries (Oladimeji, 1999; Akinwumi et al., 2011). It is also blessed with over 14 million of hectares of reservoirs, lake, ponds, and major rivers capable of producing over 980,000 metric tonnes of fish annually (FDF, 2007). Despite this large natural resource endowment and agricultural potential, poverty and hunger remain critical developmental challenges. Hence; there is a persisting paradox of a rich country inhabited by poor people which has been of great concern for many years but more especially in the last two decades.
Poverty continues to be widespread, severe and also on the increase in Nigeria. The most recent indicators of poverty such as literacy level, access to safe water and the incidence of poverty rank Nigeria below Cameroon, Mauritania and Senegal. Nigeria's Gross National Income (GNI) per capita in 2011 was also found to be far lower than that for Gabon, Angola and Algeria, while purchasing power continues to decline with high inflation and increasing income inequality. The Nigeria's Gini Index of 48.8 was above 33.0 and 44.1 for Mali and Madagascar respectively for the same period showing high level of income inequality in Nigeria (World Bank, 2011). Nigeria Human Development Index (HDI) value for 2011 was 0.459 in low the human development category, positioning the country at $156^{\text {th }}$ out of 187 countries. Using selected world developmental indicators, the life expectancy at birth in 2011 in Nigeria was 51.9 for which Nigeria is ranked $171^{\text {th }}$ out of the world's 187 countries (UNDP, 2011). This implies that there is a generalized high level of poverty in the country.

World Bank (2011) estimated the world's per capita income in 2011 to be $\$ 10,082$, compared to Nigeria per capita income of $\$ 2,069$, which made the country one of the poorest in the world. This relegated 
Nigeria to the ranks of Cameroon $(\$ 2,031)$, Mauritania $(\$ 1,859)$ and Senegal $(\$ 1,768)$. Other indicators of development such as life expectancy, for which Nigeria is ranked $171^{\text {th }}$ out of the world's 187 countries, and infant mortality, for which Nigeria is ranked $148^{\text {th }}$ among 173 countries were consistent with Nigeria's low rank in income per capita (UNDP, 2011). Based on these empirical data, Nigeria has been classified as a poor nation; a situation which can be described as a bewildering paradox given the vast resources base of the country.

However, the Nigerian economy as in many other Sub-Saharan African countries is basically agrarian with majority of the people living under poor conditions. A good proportion of the Nigerian fishing households are subsistence small holder, relying heavily on the use of non-motorized canoes and fishing nets under a traditional system characterized by low technology, low capital investment and high labour intensive practices ( Ibrahim et al., 2009). Statistical surveys have shown that the demand for fish in Nigeria exceeds supply and also the domestic production is very low despite the abundant water resources and available man power. The annual fish consumption/demand in Nigeria has been estimated to be over 1.3 million metric tonnes and the total domestic production is just about 450,000 metric tonnes per annum ( Tsadu et al., 2006; FAO, 2007).The implication of these is that the national demand has not been met which culminate in fish importation of about US\$ 400 million annually. The bulk of agricultural production especially artisanal fisheries (85\%) in Nigeria take place in the rural areas and ironically, the level and incidence of poverty is very pronounced in those areas ( FAO,2007; NBS, 2012). With the recognition by the Nigerian Government of the multi-sectoral and multidimensional nature of poverty, a number of coordinated programmes and policies had been formulated to combat poverty in all its ramifications. Some of these measures and programmes include the National Accelerated Fish Production Project (NAFPP), Integrated Rural Fisheries Development Project, Fish Storage, Processing and Marketing Scheme, the National Economic Empowerment and Development Strategy (NEEDS) (NBS, 2005).

The inter-linkages between artisanal fishery households and poverty have been major issues in the role and effectiveness of policy interventions in poverty reduction in developing countries. There is however, scanty literature on artisanal fishery households and poverty and the particular disadvantages they might encounter. A study by Etim et al (2008) concluded "that fishing is being practiced by virtually all homes in the coastal and and riverine areas. But, these activity have had limited success in increasing income and improving the quality of life. Understanding the factors underlying their persistent deprivation is important, when designing policies to meet their needs and improve their welfare. While there are national data on food security and poverty, information on rural food security and poverty are not readily available especially in Nigeria (Omotesho et al., 2010).

Meeting the Millennium Development Goal of halving the proportion of people in poverty and hunger by 2015 would require investigating and investing in rural artisanal fishery. This will require a renewed interest in fishery and agriculture as a whole due to its ability to facilitate a sustainable labour intensive growth with provision of employment for the ever increasing population in the State in line with new global agenda for poverty eradication. The results that will emanate from this study will help inform poverty eradication strategies with specific focus on rural artisanal fishery households. In view of this; the need to access the current poverty situation among artisanal fishery households in Edu and Moro Local Government Areas of Kwara State becomes imperative. The study therefore, intends to describe the socio-economic characteristics of the artisanal fishery households in the study area, identify the factors that influence poverty among artisanal fishermen and estimate its determinants.

\section{LITERATURE REVIEW}

Fish is a vital source of protein in the diet of most Nigerians including people in coastal and riverine areas. Fish also contain a number of minerals and vitamins, which are valuable components of human dietary requirements and animal feed stuff. In addition, the artisanal fishermen constitutes the most significance fishery sectors in Nigeria in terms of the number of people employed and its contribution to total fish output is very significant. But in spite of contributing substantially to domestic fish production in the country, small fishermen remains the most impoverished fisheries sub sector with fishermen generally making subsistent living (Oladimeji, 1999). Artisanal fishery occupied a significant position in the Nigerian economy providing employment for about $4.3 \%$ of Nigerian population and supplying 88.1 percent of the total domestic fish production (Ominjoyin, 2010). In this study, artisanal fishers are defined as independent fish harvesters whose 
livelihood is based on fishing on a part or full time basis, using labour and knowledge intensive fishing techniques, and employing family or community labour, often on a sharing basis, for harvesting in riverine habitats. The fish caught are normally sold in the local market, usually through middlemen, although some is for home consumption.

Poverty in absolute sense is a situation where a section of population is unable to meet its bare subsistence essentials of food, shelter and clothing in order to maintain minimum standard of living. Absolute poverty refers to the lack of the minimum physical requirements of a person or a household for existence and at its extreme those affected are no longer able to lead a life worthy of human dignity (Omonona, 2000). Relative poverty therefore exists when a person's provision with goods and services is lower than that of others. In general terms, relative poverty is the inability of individual or household to attain a given minimum contemporary standard of living and identifies those individuals or households that are the poorest within the overall pattern of income distribution within a given society.

Therefore, the entrenched poverty in artisanal fishing remains a major challenge to the country and a concern to its goal of achieving the 2020 vision and other strategies. Inaddition, the severity of poverty also suggests that the impressive economic development has by-pass the majority of the poor fishermen. The global concern about poverty is not by accident as there is a general consensus that poverty has become a pervasive and massive global outrage (Delgado et al., 1998). Etim et al., (2008) inferred that almost a billion people in the world live in chronic hunger. Seventy percent of these individuals are farmers (both arable and fishermen), women and children who make a living from small plots or poor soils and waters.

Conceptual Framework: The concept of poverty dates back to 1899, when one of the earliest and most famous studies of poverty was conducted by Seebohm Rowntree in York. Rowtree (1902) used a concept of subsistence poverty and drew a poverty line in terms of a minimum weekly sum of money, which was necessary to enable to secure the necessaries of healthy life. Poverty is more easily recognized than defined. Hence a universally acceptable definition of the term has remained elusive. However, World Bank (2001) defined poverty as an unacceptable deprivation in human well-being that can comprise both physiological and social deprivation. Physiological deprivation includes the non-fulfillment of basic material or biological needs, including inadequate nutrition, health, education and shelter. The concept of physiological deprivation is thus closely related to but can extend beyond low monetary income and consumption levels. Social deprivation widens the concept of deprivation to include risk, vulnerability, lack of autonomy, powerlessness and lack of self-respect.

Absolute poverty is a situation of lack of access to resources required to obtain the minimum necessities required to maintain physical efficiency. Relative poverty, on the hand is the inability to attain a given minimum contemporary standard of living. Poverty can also be subjective. This poverty is closely related to relative poverty since those who are defined as poor in terms of the standard of the day will probably see and feel themselves to be poor. The concept of subjective poverty is important since to some degree, people act in terms of the way they perceive and defined themselves. Poverty line is the threshold income below, which one is considered to be poor. It is the value of income or consumption expenditure necessary for a minimum standard of nutrition and other necessities. There are currently two main methods of setting the poverty line i.e., the cost of Basic Needs (CBN) and the Food-Energy-Intake (FEI) methods. The CBN approach has the advantage of ensuring consistency (treating individuals with the same living standards equally), while FEI approach has the advantage of specificity reflecting better the actual food consumption behaviour of individuals around the caloric threshold given their tastes, preferences and relative prices.

The Tobit model originates from the work of Tobin (1958) and has been extensively used by economist to measure the effect of changes in the explanatory variables $\left(\mathrm{x}_{\mathrm{i}}\right)$ on the probability of being poor and the depth or intensity of poverty (Mc Donald \& Moffit, 1980). The Tobit model can be used to determine the impact of the explanatory variables on the probability of being poor using a function. The model assumes that many variables have a lower (or upper) limit and take on this limiting value for a substantial number of respondents.

\section{METHODOLOGY}

The study was conducted in Jebba and Lafiagi in Moro and Edu Local Government Areas in Kwara State, Nigeria. The State is an inland water state naturally blessed with large volumes of water where fishermen provide food for an estimated population of about 2, 365,353 (NPC, 2006). The population is 
projected in 2012 to be $2,857,420$, representing $3.2 \%$ annual growth rate in population and an average density of eighty eight persons per square kilometre (NPC, 2006; KWADP 2011). The fishermen are predominantly in the fishing settlements/villages which are scattered along the River Niger area of the State with narrow inlets of stream, reservoir, dams and rivers such as River Niger in Patigi, Lafiagi, Jebba and their inlets (Oladimeji, 1999). It is located between latitudes $7^{\circ} 45^{\prime} \mathrm{N}$ and $9^{\circ} 30^{\prime} \mathrm{N}$ and longitude $2^{0} 3^{\prime} \mathrm{E}$ and $6^{0} 25^{\circ} \mathrm{E}$. The minimum average temperature throughout the state ranges from $21.1^{\circ} \mathrm{C}$ and $25.0^{\circ} \mathrm{C}$ while maximum average temperature ranges from $30^{\circ} \mathrm{C}$ and $35^{\circ} \mathrm{C}$.Farming including artisanal fishing is the major occupation of a large number of the people in study area. These fishing activities are usually carried out by the traditional fishing methods (such as canoes with paddles, fishing nets, hooks, gear, trap e.t.c.) and more recently few motorized boat have been introduced in the study area. The main fish species found in Pategi and Jebba include Clarias, Tilapia, Hemichromis, Barilius and Hyperopsis.

Primary data were collected from 160 artisanal fishermen selected from four fishing settlements in the study area through a multi-stage random sampling procedure using a structured questionnaire. Two Local Government Areas (LGAs) were randomly selected from the list of four fishing LGA in Kwara state. The list of fishing settlements in the two LGAs selected was drawn from which two fishing settlements each were randomly selected. Then, the list of artisanal fishermen in each settlement was compiled through co-operatives for random selection. From these, forty fishermen from each of the list of settlements were randomly chosen for interview. Therefore, a total of 160 fishermen were randomly selected in the four fishing settlements. The selected fishing villages/ were Ipata-Jebba, Kungu-Jebba, chukwura-Lafiagi and Puta- Lafiagi.

Analytical Technique: To estimate the determinants of poverty among the fishermen, limited dependent variable models provide a good framework and tobit model was used. Tobit model is an econometric and a biometric model developed by James Tobin, (1958) and has been extensively used by economist to measure the effect of changes in the explanatory variables $\left(X_{i}\right)$ on the probability of being poor and the depth or intensity of poverty (Etim and Solomon, 2010).

The model involved aspect of probit analysis and assumed that the observe dependent variable $\left(Y_{i}\right)$ for observation $\mathrm{i}$ where $\mathrm{i}=1,2, \ldots \ldots \ldots \ldots \mathrm{n}$ satisfy a condition:

$$
Y_{i}=\max \left(Y_{i}^{*}, O\right)
$$

Where the $Y_{i}^{*}$ is a latent variable. The variable linearly depends on $\beta$ which determine the relationship between the independent variable $X_{i}$ and the latent variable $Y_{i}^{*}$. In addition, there is a normal distributed error term $U_{i}$ to capture random influences on the relationship. The observable variable $Y_{i}$ is define to be equal to the latent variable $Y_{i}{ }^{*}$ whenever the latent variable is above zero and zero otherwise. Where you have value to be positive, $Y_{i}$ is equal to $Y_{i}^{*}$ where $Y_{i}^{*}$ is a latent variable since the value is force out of 0 and 1 , then it is out of probability. The tobit model can be used to determine the impact of the explanatory variables on the probability of being poor. The model assumes that many variables have a lower (or upper) limit and take on these limiting values for a substantial number of respondents. For the remaining respondents, the variable takes on a wide range of values above (below) the limit. The model measures not only probability that a farmer is poor but also the intensity of poverty (Tobin, 1958).

The model is also expressed based on Tobin (1958) as

$$
\begin{aligned}
& Y_{i}=P_{i}=\left(X_{i} \beta, u\right) \text { if } P_{i}>P_{i}^{*} \\
& O=\left(X_{i} \beta, u\right) \text { if } P_{i} \leq P_{i}^{*} \\
& i=1,2, \ldots \ldots \ldots . .160 \text { samples. }
\end{aligned}
$$

Where $Y_{i}$ is the dependent variable, it is discrete when the households are not poor and continuous when they are poor.

$P_{i}$ is the poverty depth/intensity defined as $\left(Z-Y_{i}\right) / Z$ and $P_{i}^{*}$ is the poverty depth. When poverty line $(Z)$ equals the expenditure per adult equivalent, $X_{i}$ is a vector of explanatory variable. $\beta$ is a vector of unknown co-efficient and it is an independently distributed error term.

The explanatory variables specified as determinants of poverty are:

$$
\begin{aligned}
& X_{1}=\text { age of the household head in years } \\
& X_{2}=\text { sex of the household }(D=1 \text { if female, } 0 \text { if }
\end{aligned}
$$

male)

$X_{3}=$ marital status of the household head $(D=$ 1 if married, 0 if otherwise)

$$
\begin{gathered}
X_{4}=\text { number of household size } \\
X_{5}=\text { years of formal education }
\end{gathered}
$$


$X_{6}=$ cost of fishing equipment in Naira

$X_{7}=$ fishing income in Naira

$\mathrm{X}_{8}=$ labour employed in Labour hours

$\mathrm{X}_{9}=$ fishing experience in years

\section{RESULTS AND DISCUSSION}

Table 1 show that majority of the pooled fishermen $(87.5 \%)$ had age ranged of $31-50$ years. All things been equal, labour productivity is a function of age. It is believed that old people tends to adhere strictly to traditional methods of production while young people tends to be more willing to adopt new production methods in order to increase fish output . The marital status shows that majority of the 144 respondents $(90 \%)$ of the fishermen are married. Marrying more than one wife is common in rural settings either to ensure supply of additional family labour or to raise the status of the farmer in an illiterate setting. Analysis shows that male dominate the ownership of artisanal fishing ventures in the state. Only $9.4 \%$ of the respondent were females and engage in actual fishing. Therefore women do not usually engage in fishing operations, particularly when it involves actual fish caught, rather, women are engaged in processing and marketing of the fish and fish product. On the household size, the average numbers of persons per fisherman were approximately seven with six to ten children as modal class. This result shows that most of the population explosion occurs in the rural areas. However, they are important in the supply of family labour in fishing activities. The literacy rate was very low among the fishermen. From the table above, the bulk $69.4 \%$ of the pooled fishermen did not have formal schooling. This implies that artisanal fisheries operations in the state were performed mostly by illiterates. This could affect their chances of using improved and sophisticated motorized canoes and fishing gears which requires skilled training and reading manuals.

Tobit Regression Results: From the maximum livelihood estimates (MLE) of the tobit regression in table II, the results show that sigma $(\delta)$ was 0.5873 with a Z-value of 3.4138 and is significant at one per cent level. Therefore, the model has a good fit to the data and that the model as specified explained significant non-zero variations in factors influencing poverty. The co-efficient of sex of the household head $\left(\mathrm{X}_{2}\right)$ is 0.3201 . This implies that the poverty depth is decrease by 0.3201 for male headed households to become 0. 0926. Female headed households will have a poverty depth of 0.4127 . This could be attributed to the involvement of maleheaded households in different forms of off-farming activities. The findings were supported by Etim and Solomon (2010). The co-efficient of marital status of household head $\left(X_{3}\right)$ is 0.043 implying that the poverty status of household headed by married people will be increased by 0.043 to become 0.4127 , while that of household headed by unmarried people will remain as 0.043 . However, the said value was not significant.

\section{Table 1: Socio-Economics Characteristics of Artisanal fishermen in the study area}

\begin{tabular}{|c|c|c|c|}
\hline DISTRIBUTION & FREQUENCY & $\begin{array}{l}\text { RELATIVE } \\
\text { FREQUENCY } \\
\text { (\%) }\end{array}$ & $\begin{array}{l}\text { CUMMULATIVE } \\
\text { FREQUENCY }\end{array}$ \\
\hline \multicolumn{4}{|l|}{ Gender } \\
\hline Male & 144 & 90.6 & - \\
\hline Female & 16 & 9.4 & 160 \\
\hline \multicolumn{4}{|l|}{ Age (years) } \\
\hline $21-30$ & 13 & 8.1 & - \\
\hline $31-40$ & 72 & 45.0 & 85 \\
\hline $41-50$ & 68 & 42.5 & 153 \\
\hline $51-60$ & 06 & 3.8 & 159 \\
\hline Above 60 & 01 & 0.6 & 160 \\
\hline \multicolumn{4}{|l|}{$\begin{array}{l}\text { Educational } \\
\text { Level }\end{array}$} \\
\hline $\begin{array}{l}\text { No Formal } \\
\text { Schooling }\end{array}$ & 111 & 69.4 & - \\
\hline $\begin{array}{l}\text { Primary } \\
\text { Education }\end{array}$ & 36 & 22.5 & 147 \\
\hline $\begin{array}{l}\text { Secondary } \\
\text { Education }\end{array}$ & 12 & 7.5 & 159 \\
\hline $\begin{array}{l}\text { Tertiary } \\
\text { Education }\end{array}$ & 01 & 0.6 & 160 \\
\hline \multicolumn{4}{|l|}{$\begin{array}{l}\text { Household } \\
\text { Size }\end{array}$} \\
\hline None & 11 & 6.9 & - \\
\hline $1-5$ & 49 & 30.6 & 60 \\
\hline $6-10$ & 74 & 46.3 & 134 \\
\hline $11-15$ & 24 & 15.0 & 158 \\
\hline $16-20$ & 2 & 1.3 & 160 \\
\hline Total & 160 & $100 \%$ & \\
\hline
\end{tabular}

Source: Field Survey 2010 
Agric. Biol. J. N. Am., 2013, 4(4): 422-429

Table 2 Maximum livelihood estimates of determinant of poverty

\begin{tabular}{|l|c|c|c|}
\hline Variable & Co-efficient & $\begin{array}{c}\text { Standard } \\
\text { Error }\end{array}$ & Z-value \\
\hline Sex of household head $\left(\mathrm{X}_{2}\right)$ & $0.3201^{*}$ & 0.1632 & 1.9614 \\
\hline Age of household head in years $\left(\mathrm{X}_{1}\right)$ & 0.2971 & 0.2263 & 1.3129 \\
\hline Marital status of household $\left(\mathrm{X}_{3}\right)$ & 0.043 & 0.2346 & 0.1833 \\
\hline Household size $\left(\mathrm{X}_{4}\right)$ & $0.3271^{*}$ & 0.1648 & 1.9852 \\
\hline Education level $\left(\mathrm{X}_{5}\right)$ & $-0.3167^{*}$ & 0.1628 & 1.9451 \\
\hline Cost of fishing & & & \\
\hline Equipment $\left(\mathrm{X}_{6}\right)$ & $0.4023^{*}$ & 0.2080 & 1.9341 \\
\hline Fishing income $\left(\mathrm{X}_{7}\right)$ & $0.2510^{\star *}$ & 0.1015 & 2.4718 \\
\hline Labour employed $\left(\mathrm{X}_{8}\right)$ & $0.2961^{\star * *}$ & 0.0847 & 3.4959 \\
\hline Fishing experience $\left(\mathrm{X}_{9}\right)$ & 0.3140 & 0.2470 & 1.2713 \\
\hline Constant & $0.2468^{* *}$ & 0.1186 & 2.0809 \\
\hline Sigma & 0.5873 & 0.1720 & 3.4138 \\
\hline
\end{tabular}

Source: tobit Regression result, 2010

${ }^{* * *}$ Significance at $1 \%$; ${ }^{* *}$ significance at $5 \%$; ${ }^{*}$ significance at $10 \%$

The co-efficient of years of formal education $\left(X_{5}\right)$ is 0.3167 . This implies that the poverty depth is decreased by 0.3167 for individuals in families whose heads have formal education to become 0.0960 . Households without formal education have a poverty depth of 0.4127 . This may be attributed to the fact that highly educated household heads have the ability to adopt improved fishing techniques faster than non-educated ones. This however increases the productivity and incomes of the educated heads with attendance improvement in welfare amongst them. This supported the findings of Schubert (1994); FOS (1999); Oladimeji (1999); Olorunsanya (2009) and Etim and Solomon,(2010). It also shows that most fishermen has no formal education and this could affect their chances of using improved and sophisticated motorized canoes and fishing gears which required skilled training and reading manuals to learn modern fishing techniques.

The household size $\left(X_{4}\right)$ has a co-efficient of 0.3271 ; this means that a unit increases in the household size will raise poverty by $32.71 \%$. This is obvious because most household particularly children contribute less to family labour and income. The family on the other hand, spends money for feeding them, educating and training them in school and crafts. Similar findings were reported by World Bank (1991), Schubert (1994); Oladimeji (1999); Etim et al., (2008) that a larger sized household is associated with greater poverty incidence.

The regression co-efficient for cost of fishing equipment $\left(X_{6}\right)$ is 0.4023 , implying that a unit increase in fishing equipment would increase the poverty level by $40.23 \%$. This is true because crude fishing techniques which are predominant leads to decrease income and reduction in welfare. Findings were in line with Oladimeji (1999).

The coefficient for fishing income of household head $\left(X_{7}\right)$ is 0.2510 ; this implies that the poverty depth is decreased by $25.10 \%$ for individuals. As the income of the farmer's increase his poverty level will decrease, Ceteris Paribus. The report is synonymous with Etim and Solomon, (2010).

The regression co-efficient for labour employed $\left(X_{8}\right)$ in fishing operations is 0.2961 , the results show that a man-day rise in labour employed in fishing operations will raise the poverty depth by $29.61 \%$ as it was also reported by oladimeji (1999), Etim and Solomon (2010), that increase in family labour is as a result of more household members,but tends to raise the poverty status of households. 
The regression co-efficient of fishing experience of the fishing household $\left(\mathrm{X}_{9}\right)$ was 0.3140 meaning that a unit increase in fishing experience of the household head would lead to $31.40 \%$ increase in poverty. Similar finding were reported by oladimeji, (1999), Etim (2007) and Etim and Solomon (2010) with assertion that as fishing experience increases, the age of the household head also increases. This however, leads to a reduction in the fishing operations with subsequent reduction in fishing income and welfare.

\section{CONCLUSION AND RECOMMENDATIONS}

The research focused the artisanal fishing farm level estimation of the determinants of poverty through the application of tobit regression model. Maximum likelihood estimates, co-efficient and standard error were derived from a specified Tobit regression model estimated by maximum likelihood estimation procedure. The estimated parameters were unbiased, more efficient and consistent. The estimation of the determinants of the poverty among fishing households reveals that except for age, marital status and fishing experience, all other exogenous variables markedly and aptly contribute to poverty among the fishing households in the state. However, it is recommended, therefore, that artisanal fishermen in the study area should be educated to ensure proper understanding of new fishing methods and adopt technology capable of increasing not only the profitability of the enterprise and improvement in the quality of life of rural households but also make efficient use of the fishing resources.

\section{REFERENCES}

Akinwumi, F.O., Akinwumi, I.O. and Ogundahunsi, O.A. (2011). Characterization of Artisan Fishery in the Coastal Area of Ondo State, Nigeria. International Research Journal of Agricultural Science and Soil Science. 1(3): 83-89

Delgado, C.L. and Courbois, C. (1998). Trade-offs among fish, meat and milk demand developing countries from the 1970's to the 1990's. In: Eide, A. and T. Vassdal (eds.), Porc. The Biennial Meetings of the Int. Institute of Fisheries Econ. and Trade. Tromso, Norway: The Norwegian College of Fishery Science.

Etim, N.A. (2007). Analysis of Poverty Status of Rural Farm Households in Akwa Ibom State, Nigeria. Unpublished $\mathrm{PhD}$ Dissertation. University of Agriculture, Umudike. Abia State. Department of Agricultural Economics, Micheal Okpara University of Agriculture, Umudike. Nigeria.

Etim, N.A., Esu, B.B., Edet, G. E., Okon, S. and Solomon, I. P. (2008). Poverty among Peri- Urban Farming
Households: An Estimation of its Determinants. In: Osakwe, I.I., Ekwu, L. G., Utobo, E.and Mbah, C.N. (eds.), Proceedings of 42nd Annual Conference of Agricultural Society of Nigeria Eds. Ezike, held at Ebonyi state University, Abakaliki, pp: 877-880. 1923 October, 2008

Etim, N.A. and Solomon V. A. (2010). Determinant of Rural Poverty among Broiler Farmers in Uyo, Nigeria: Implications for Rural Household Food Security. Journal of Agriculture and Social Sciences, 6: 24-28

Federal Department of Fisheries (FDF) (2007). Fisheries Statistics of Nigeria, FDF Publication, Abuja FCT, Nigeria. 11-24PP

Federal Office of Statistics (FOS) (1999). Poverty Profile for Nigeria 1980-1996, pages 12-15. FAO Report, Abuja, Nigeria.

Food and Agriculture Organization, (2007). The State of World Fisheries Aquaculture 2006.Food and Agricultural Organization of the United Nations, Rome. Pp:162.

Food and Agriculture Organization, (2013). FAO Country Programming Framework (CPF) Federal Republic of Nigeria, Fiat Panis, pp 1-41

Ibrahim, B. U., Auta, J. And Balogun, J. K. (2009). A Survey of the Artisanal Fisheries of Kontagora Reservoir, Niger State, Nigeria. Bayero Journal of Pure and Applied Sciences, 2(1) : 47-51.

Kwara Agricultural Development Projects (KWADP) (2011), Annual Report, July, 2011.

Mc Donald, J.D. and Moffitt, R. A. (1980).The Uses of Tobit Analysis, Review of Economics and Statistics, Vol. 62: pp 318-21.

National Bureau of Statistics (NBS) (2005). Poverty Profile for Nigeria. Annual Report Federal Republic of Nigeria. 2005.

National Bureau of Statistics (NBS) (2012). Poverty Profile for Nigeria. Annual Report, Federal Republic of Nigeria. 2012.

National Population Commission (NPC) (2006). Population Census of the Federal Republic of Nigeria. Analytical Report at the National Population Commission, Abuja, Nigeria.

Oladimeji, Y. U. (1999). An Economic Analysis of Artisanal Fisheries in Kwara State, Nigeria. Unpublished MSc Thesis. Federal University of Technology, Akure, Nigeria.

Olorunsanya, E. O. (2009). Gender of Households Heads and Relative Poverty among Rural Farming Households in Kwara State. Unpublished PhD Thesis, Department of Agricultural Economics and Extension, University of Ilorin. Ilorin. Nigeria 
Omijoyin, S.A. (2010). Credit Utilization in Ameliorating the Impact of Climate Change for Food Security among Artisan Fisheries in Lagos, Lagoon, Nigeria. PDF Commerce Special Edition, 2010.

Omonona, B. T. (2000). Poverty and Its Correlates among Rural Farming Households in Kogi State, Nigeria. Unpublished PhD Thesis, Department of Agricultural Economics, University of Ibadan, Ibadan. Nigeria.

Omotosho, A. O., Adewumi, M. O., Fadimula, K. S. (2010).Food security and Poverty of Rural Households in Kwara State Nigeria. Libya Agricultural Research Center journal International, volume 1 (1) :56-59 Idosi publications.

Rowtree, B. S. (1902) Poverty: A Study of Town Life. Macmillan and Co., Limited, London.

Schubert, R. (1994). Poverty in Developing Countries : Its Definition, Extent and Implications, Economics 49/50 : 17-40.

Tobin, J. (1958). Estimation of Relationship for Limited Dependent Variables. Econometrical 26: pp 26-36.
Tsadu, S. M., Ojutiku, R. O. And Anyawale A. V. (2006). A Survey of Fungi Contamination of some Fish Species from Tagwai Daru, Minna, Niger State, Nigeria. Journal of Tropical Biosciences. 6: 1-5pp.

Udolis. R.E.K., solam, B.B. and Ambrose, E.E. (1994). A Catalogue of Small Scale Fishing Gears in Nigeria. IAFR publisher. $1084 \mathrm{~F}_{1} 194$ :102- 142.

United Nations Development Program (UNDP) (2011). Human Development Report. Oxford University Press, New York. Pp 127-130.

World Bank (1991). World Development Report. Annual Report 1991. New York. Oxford University Press.

World Bank (2001). World Development Report 2000/2001. Annual Report 2000/2001. Washington D.C.

World Bank (2011). World Development Indicator, Human Development Index Report, New York. Oxford University Press. 